Запропоновано новий принцип управління температурою та масовою витратою металевого розплаву при його безперервному розливанні. Встановлено, що таке управління може здійснюватися на основі постійного контролю маси рідкого сплаву в ливарних та металургійних агрегатах і відповідного регулювання системами обладнання. Використання для впливу на рідкометалеве середовище електромагнітних полів та магнітогідродинамічних (МГД) чинників є ефективним засобом забезпечення необхідих технологічних та техніко-економічних показників процесу безперервного розливання. Запропоновано відповідну принципову конструктивно-функціональну схему системи автоматичного управління (САУ) процесом безперервного розливання сплавів, яка грунтується на застосуванні магнітодинамічного проміжного ковша (МД-ПК) $і$ магнітовагової системи. Визначено їх основні конструктивні особливості та функціональні можливості стосовно до процесів безперервного розливання як у порівнянні з існуючим обладнанням, так $і$ з системами аналогічного призначення. Пропонуеться реалізувати МД-ПК у вигляді двокамерного агрегату, в якому розділені функиї прийому розплаву зі сталерозливного ковша, нагрівання рідкого металу, видачі його $y$ кристалізатор машини безперервного лиття заготівок (МБЛЗ). Стабілізація витратного режиму розливання, у тому числі малонапорного, здійснюється за рахунок постійного контролю маси розплаву в системі та відстеження його рівня у випускній камері МД-ПК і кристалізаторі МБЛЗ.

Розроблений спосіб та створювані агрегат, система $і$ допоміжні пристрої дозволять суттево удосконалити сучасні технологї безперервного лиття

Ключові слова: безперервне розливання, магнітодинамічний проміжний ківш, масова витрата, система автоматичного управління

$\square$

口-

Received date 03.05.2019

Accepted date 27.06.2019

Published date 12.08.2019

1. Introduction

At present, technologies of continuous steel casting play one of the leading roles in terms of improving the efficiency of metallurgical production and ensuring high quality of steel products. Therefore, the scientific and applied research into the processes that accompany continuous steel casting is extremely relevant and promising, being undertaken intensively in the leading industrialized countries. The main tasks addressed in the framework of specified studies are related primarily to improving the structure and properties of continuously-cast workpieces, quality of their outer surface, as well as increasing production efficiency.

An unquestionable advantage of existing technologies is their wide application and thoroughly tested operations. However, this is also their main drawback as the opportunities to improve existing technologies through a more complete implementation of scientific concepts and engineering

\section{DEVELOPMENT OF PRINCIPLES TO CONTROL THE PROCESSES OF CONTINUOUS CASTING OF ALLOYS USING MAGNETODYNAMIC EQUIPMENT}

V. Du bodelov

Doctor of Technical Sciences, Professor, Academician of the National Academy of Sciences of Ukraine, Head of Department* E-mail: mgd@ptima.kiev.ua

A. Se m e n k o Junior Researcher*

E-mail: www.sem.a.u@gmail.com

$K$. Bogd a n

Doctor of Technical Sciences, Senior Researcher*

E-mail: kimbogdan889@gmail.com

M. G o r y u k

PhD, Deputy Head of Department* E-mail: gormak72@gmail.com

*Department of Magnetohydrodynamics Physico-Technological Institute of Metals and Alloys of the National Academy of Sciences of Ukraine Vernadskoho blvd., 34/1, Kyiv, Ukraine, 03142

\footnotetext{
Copyright (C) 2019, V. Dubodelov, A. Semenko, K. Bogdan, M. Goryuk This is an open access article under the CC BY license (http://creativecommons.org/licenses/by/4.0)
}

developments inherent to them are almost exhausted. Further advancement occurs only due to enhanced technological culture, the application of new materials, computer equipment, and by improving design of separate nodes.

One of the main issues is the fact that continuous steel casting requires ensuring at all stages of the process a widerange low-inertial control over the thermal and hydrodynamic state of liquid metal. It is also advisable to ensure that all the listed operations are carried out in a single multifunctional unit.

Stability of the process of continuous casting of metal melts and, therefore, the quality of billets obtained is largely determined by technological parameters in the chain: «steel casting ladle - tundish - crystallizer». Maintaining a constant level of melt in a crystallizer can be achieved only in the presence of high-speed controls that make it possible to regulate the flow of melt with the required precision. In addition, given the high dynamics of the continuous casting process, 
it is also a relevant task to strictly comply with the predefined temperature of the melt. This is also the responsibility of a control system, based on control over the mass and/or level of a liquid-metal bath in a tundish and on appropriate regulation of the heating power.

Thus, one of the promising fields of research is to develop a scientific base for creating new high-performance multifunctional tundishes for the processes of continuous casting. Such unique assemblies must be integrated into the structure of continuous casting machines (CCM), to ensure that outof-furnace melt processing operations, which are typically implemented in assemblies of the type «furnace-ladle» are transferred to a tundish.

\section{Literature review and problem statement}

The efficiency of induction heating, when compared with electric arc and plasma sources, commonly used in tundishes and whose thermal and electrical efficiency is at the level of $0.55-0.75$, reaches $0.80-0.85$ [1]. That is why the Kawasaki Steel Corporation designed an induction tundish with a capacity of 5 tons for the technology of continuous casting of slabs from high-quality stainless steel $[2,3]$. Such a development made it possible to almost completely eliminate the defects of continuously-cast workpieces that are associated with the instability of thermal modes of casting. Thus, the casting of steel from a conventional tundish is accompanied by a substantial fall in the temperature of the melt (exceeding $10^{\circ} \mathrm{C}$ ) over a relatively long time, in terms of the dynamics of the process (3-6 min). Therefore, at certain stages of the casting process (start of pouring, changing the steel bucket, etc.) a significant electrical energy must be supplied to the melt - at the level of 300-500 kW (depending on the weight of metal in a tundish).

However, such a unique assembly has not been widely applied in the industry, due primarily to the imperfect system to control the feed of melt into the crystallizer of CCM. Such a system is based on the use of insufficiently reliable stopper or slide gates that are in contact with liquid steel. Attempts to create a non-contact electromagnetic gate succeeded only for model substances of the type of a Wood alloy [3]. Because of poor electrical properties of steel, large nonmagnetic gaps, and limited space in the place where a gate is installed, such a device cannot be at present fabricated for actual production processes of continuous casting of steel at industrial CCM.

In order to heat metal and remove non-metallic inclusions (NI), it is proposed to employ tundishes, including two-chamber, with additional electromagnetic systems, first of all inductors [4-7]. Thus, there is a known tundish equipped with an induction unit, which, in addition to the induction heating of liquid steel, enables the removal of nonmetallic inclusions from it due to the use of the phenomenon of pinch effect and different electrical properties of metal and NI [6, 7].

Another design of the so-called two-chamber centrifugal tundish implies separating that part of the tundish cavity with partitions, which receives liquid metal from a steel casting ladle. This cavity is covered by a semi-circular rotating magnetic field inducer that generates a rotating movement of the melt in it and excludes the penetration of NI into the tundish bath and further to the crystallizer of CCM [8]. However, the effective work of such a system depends on the ratio of height of the inductor to the level of melt in a tundish in order to prevent the mixing of slag from the surface deep into a liquid-metal bath.
In addition, all the considered devices have significant deficiencies [9,10]. First, this is the above-mentioned application of stopper or slide gates that are susceptible to fouling and destruction. Second, such tundishes enable the casting of metal under a significant metal-static pressure, which causes a high linear velocity of the melt $(3-5 \mathrm{~m} / \mathrm{s})$ that arrives into the crystallizer of CCM, as well as the related defects of the structure. One should also note the issues of stability in the casting process (capture of films, NI, gases into the body of a workpiece, a deep liquid-metal hole, crushing of the crust and increasing the danger of its disruption, etc.). To avoid such negative consequences, they apply special expensive devices for electromagnetic braking of high-speed flows of steel in the crystallizer of CCM, the type of EMBR (Electromagnetic Brake) [11-13].

Therefore, we can confidently state that the developments aimed at improving the continuous casting processes undergo certain scientific and technological stagnation. The reason is the exhausted capabilities of existing equipment and the lack of new approaches that could dramatically improve the technical and economic parameters of the process. Similar studies, including those in which the tundish gains an increasing functional weight as a technological unit, are undertaken abroad [14, 15].

\section{The aim and objectives of the study}

The aim of this study is to devise theoretical principles and approaches in order to improve the processes of continuous casting of alloys, specifically by using the original equipment and modern means of control and management of basic technological parameters. This would make it possible to create preconditions for improving the quality of cast steel products and enhancing the technical and economic indicators for casting technologies.

To accomplish the aim, the following tasks have been set:

- to propose, based on the performed analysis of existing technologies for casting alloys, as well as equipment for their implementation, new samples of metallurgical equipment with advanced design and enhanced functionality;

- to formulate basic principles for the organization and practical implementation of the examined technological process, applying the proposed newest equipment;

- to build a general scheme for managing the examined technological process based on control over the temperature and flow rate characteristics.

\section{Substantiating the necessity to use original equipment for continuous casting and to construct a principal diagram of the process, as well as a control system}

\section{1. Features of the design and operation of the origi- nal magnetodynamic tundish}

It is proposed to use a magnetodynamic tundish (MD-T) as the above-specified autonomous multifunction device, which could efficiently and effectively manage the heat and hydrodynamic parameters at continuous casting of steel. Such an assembly was built based on a magnetodynamic mixerbatcher for superheating and casting of cast iron and steel designed by the Physical-Technological Institute of Metals and Alloys at the Ukraine's National Academy of Sciences [16]. Similar MDI assemblies have advanced functionality for heating a liquid metal, averaging its temperature and 
chemical composition, for the out-of-furnace melt processing operations, which ensures improved quality of a continuously-cast billet and effectiveness of the process of casting.

The MD-T under construction includes in its structure (Fig. 1): a crucible, an induction channel, and a casting unit. The induction part is composed of: an induction channel, rectangular in cross-section, of the U-shaped, W-shaped, or a more complex shape; one to three inductors; one or two electromagnets and drain discharges.

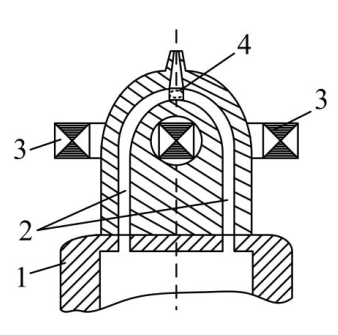

$a$

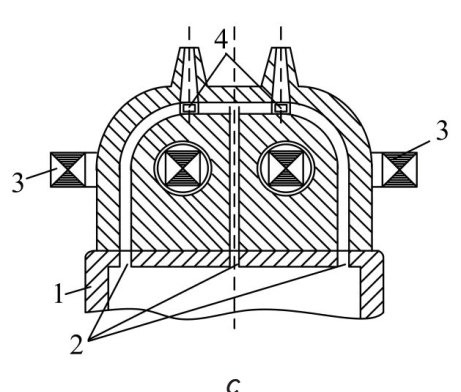

C
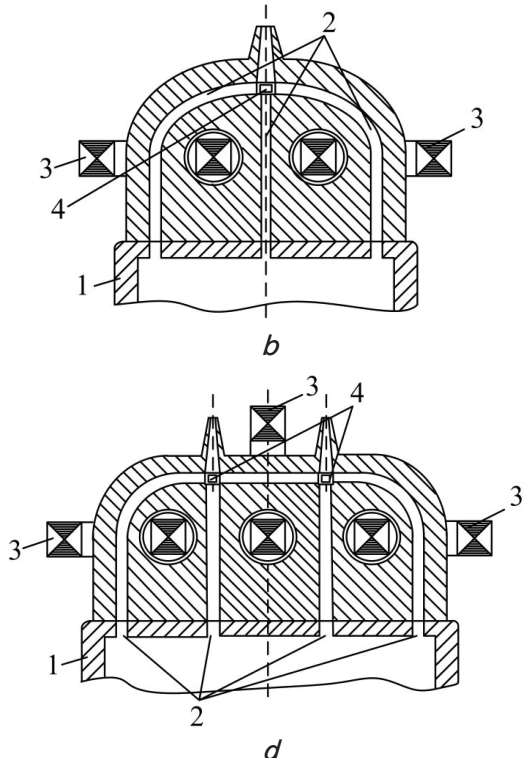

Fig. 1. Execution variants of the structure of induction part in a magnetodynamic mixer-batcher (horizontal arrangement, top view): $a$-one-inductor execution; $b, c-$ two-inductor execution with a varying number of electromagnets and drain discharges; $d-$ three-inductor execution; 1 - crucible; 2 - branches of the induction channel; 3 - inductor; 4 - working area of the melt level in them over a casting cycle is $0.7-1.1 \mathrm{~m}$. For the case of replacing a casting ladle upon pouring the entire mass of the melt from it into a tundish, there occurs, until a new ladle is received, a substantial decrease in the level, meaning there is a periodically repeated process to decrease/increase the level of melt $H$ in a tundish over the time of casting $\tau_{n}$ (Fig. 2).

In this case, one should prevent the decrease below $\sim 0.4 \mathrm{~m}$, since in such a case, above the zones of release of a liquid metal (above the outlet hole of a steelcasting cup, submerged above the level of melt in the crystallizer of CCM), because of the action of several hydrodynamic factors, a funnel is formed [10].

This leads to the capture of slag from the surface a liquid-metal bath and of air above the metal's mirror.

Consequently, non-metallic inclusions and gases penetrate the crystallizer of $\mathrm{CCM}$ and cause defects to the body of a continuously-cast billet.

The specified advantages of MD-T have made it possible to analyze its operation in terms of ensuring the process stability under a mode of continuous casting of metal and rationalizing its energy and technological parameters. In this case, it is necessary to maintain the heat balance of a liquid metal, which is at each time point in MD-T, arrives to it from a steel-casting ladle and pours from MD-T into a crystallizer.

Under conditions of periodic replenishment of MD-T with melt, the balance is described by the following pattern:

$$
\begin{aligned}
& \eta_{\text {el }} \cdot \eta_{\text {therm }} \cdot P_{\text {ind }} \cdot\left(\tau_{c}+\tau_{c+\text { pour }}\right)+ \\
& +\left(M \cdot t-Q_{\text {pour }} \cdot \tau_{p} \cdot t_{c}-M_{t . u} \cdot \Delta t^{\prime}\right) \cdot c=0 .
\end{aligned}
$$

The main features of the magnetodynamic mixer-batcher and, accordingly, the MD-T under construction are:

1) the presence of two autonomous electrical systems inductor and electromagnet. The inductor is used to heat a metal while the electromagnet generates over a certain section of the channel (in the working area) a variable magnetic field that interacts with the electric current in the channel. The resulting electromagnetic force sets the melt in motion. This technical solution makes it possible to independently manage the modes of heating and casting a melt by adjusting the heat release in the metal and its motion under the action of electromagnetic forces;

2) horizontal arrangement of the induction part. Such a design facilitates the operation of the assembly, and the selection of metal for casting occurs from a heating zone. Thus, we can hold the melt in a crucible at a lower temperature and superheat the metal to a casting temperature directly at the time of its release from a mixer, which makes it possible to greatly reduce the energy cost of the process;

3) the possibility of casting a melt under a low metalstatic head.

\section{2. Principal diagram of the process of continuous} casting using the magnetodynamic tundish

An analysis of the tundish operation at CCM of conventional design has revealed $[4,10,17]$ that the average height

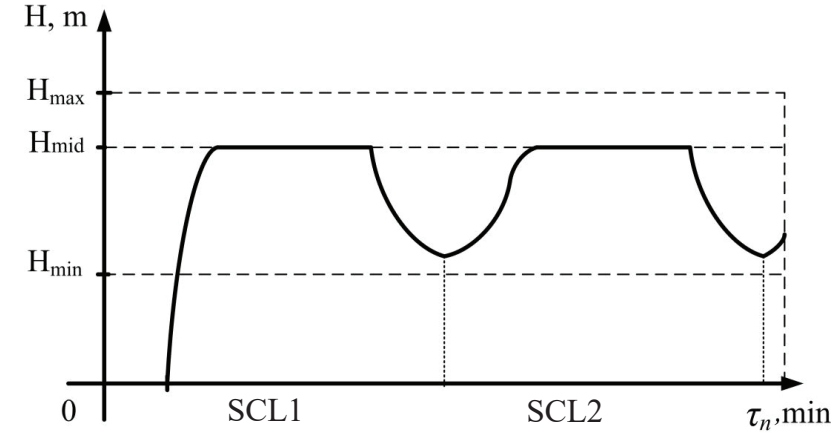

Fig. 2. Character of change in the level of melt in a tundish at continuous pouring and periodic replenishment from the new steel-casting ladle: SCL1, SCL2 - time to pour the melt from steel casting ladles 1 and 2 to MD-T

In expression (1), part of components describe the parameters for MD-T: $\eta_{e l}$ and $\eta_{\text {term }}$ are, respectively, the electric and thermal coefficient of efficiency of MD-T; $P_{\text {ind }}$ is the power of inductor at $\mathrm{MD}-\mathrm{T}, \mathrm{kW} ; M$ is the mass of a metal in MD-T, $\mathrm{kg}$. Other components are related to temperature, time, and flow rate parameters for the technological process of casting itself. The time parameters include: $\tau_{c}$ is the time during which the melt from MD-T is released into a receiving device, s; 
$\tau_{c^{+} \text {pour }}$ is the time during which there is the simultaneous casting of a metal from MD-T and replenishing it with a new portion of the melt, s. The exclusive thermal factors of the process are: $t$ is the temperature of metal in $\mathrm{MD}-\mathrm{T},{ }^{\circ} \mathrm{C} ; t_{c}$ is the assigned temperature of casting, ${ }^{\circ} \mathrm{C}$; $c$ is the heat capacity of melt, $\mathrm{J} /\left(\mathrm{kg} \cdot{ }^{\circ} \mathrm{C}\right) ; \Delta t^{\prime}$ is the magnitude for the required superheating of melt in $\mathrm{MD}-\mathrm{T},{ }^{\circ} \mathrm{C}: \Delta t^{\prime}=t_{c}-t_{\text {pour }},{ }^{\circ} \mathrm{C}$. The mass and flow rate indicators are as follows: $Q_{\text {pour }}$ is the mass flow rate of metal at pouring, $\mathrm{kg} / \mathrm{s} ; M_{t . u}$ is the mass of a portion of metal that is additionally poured to MD-T, kg.

For the completely continuous processes (continuous post-pouring of melt to MD-T and uninterrupted release of metal from it to the receiving device), condition (1) takes the form:

$$
\eta_{e l} \cdot \eta_{\text {therm }} \cdot P_{\text {ind }}-\left(Q_{\text {pour }} \cdot t_{c}+Q_{t . u} \cdot \Delta t^{\prime}\right) \cdot c=0,
$$

where $Q_{t . u}$ is the mass flow rate of metal at additional pouring to $\mathrm{MD}-\mathrm{T}, \mathrm{kg} / \mathrm{s}$.

In order to execute such a regime of control over the process of continuous casting, a two-chamber MD-T was proposed. Control over the flow rate of a metal melt is performed by controlling the mass of the melt and its level in the chambers at MD-T and in a crystallizer of CCM $[18,19]$.

\section{3. Construction of a structural-functional circuit of MD-T ACS}

We have proposed a new technical solution to control the flow of melt from a casting ladle to the crystallizer, based on the use of a two-chamber MD-T with a magneto-weighting control over the melt flow rate (Fig. 3).

A two-chamber MD-T includes in its structure: receiving and release chambers, which are the connected containers joined by an induction channel. There is a steady adjustable induction heating of a liquid metal that is directly supplied to casting, since the melt from the release chamber is continuously fed to a crystallizer. The magnitude for such superheating in the process of pouring depends on the geometry of an induction channel and the power of an inductor. The experimental-industrial validation of the proposed solution for heating a melt directly in the process of its casting was in due time carried out under conditions of a foundry shop using an active magnetodynamic mixer-batcher for cast iron and steel [16].

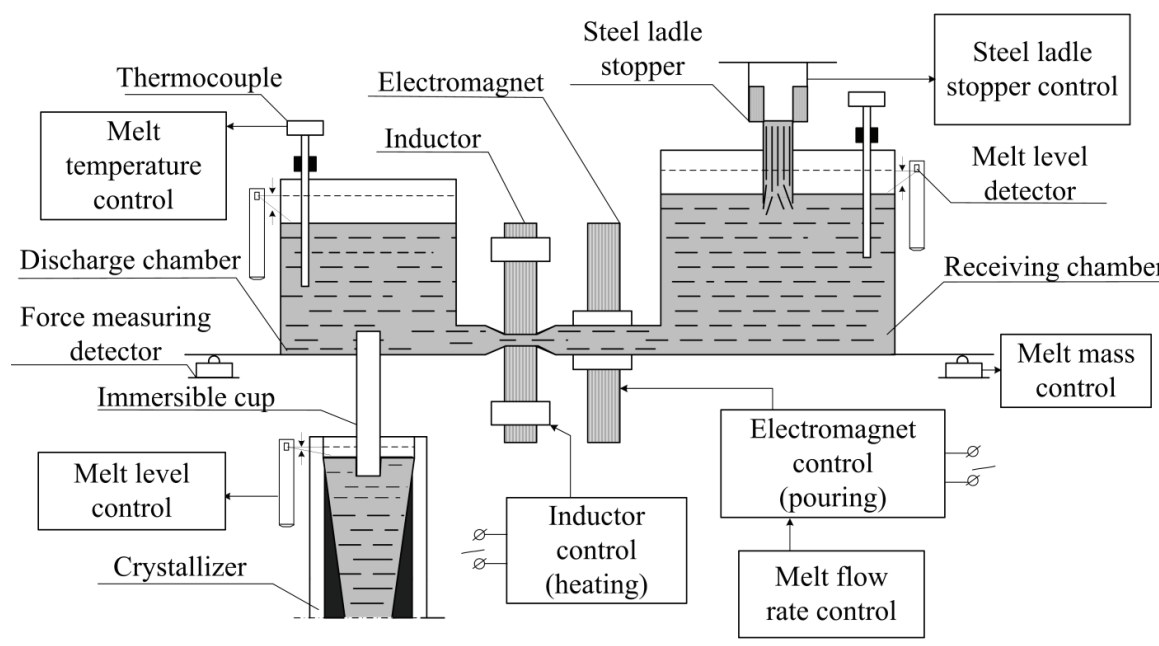

Fig. 3. Structural-functional circuit of MD-T ACS for the processes of continuous casting of melts
The induction part of the mixer was executed in the form shown in Fig. 1, $b$. The full capacity of the mixer-batcher was 4 tons of iron-carbon melt, the total maximum capacity of two inductors was $300 \mathrm{~kW}$. Dimensions of the central branch of the induction channel through which under the action of electromagnetic forces a metal passes from a crucible to a drain discharge are as follows: length $-1.1 \mathrm{~m}$; cross-section - rectangular, $0.12 \times 0.09 \mathrm{~m}$. We examined the difference in temperature of a liquid metal between the crucible and the drain discharge of the mixer-batcher, which is enabled by heating the melt during its movement. It was established [16] that depending on the motion modes of melt and the power of inductors the magnitude for superheating is not less than $10^{\circ} \mathrm{C}$ (under conditions of periodic pouring of castings at a foundry line). The process of continuous casting is distinguished by the mass velocities of metal motion that are 3-5 times higher than at dosing under conditions of a foundry shop. Therefore, the capacity of inductors should be increased in order to ensure the comparable thermal parameters.

In addition, the inductor is involved in the generation of an electromagnetic force. An additional electromagnet at a certain section of the induction channel induces an external variable magnetic field. The generated field interacts with induction current in the channel and, as a result of superposition of fields, there generates a volumetric electromagnetic force that provides for the motion of melt between the chambers. Depending on the modes of enabling the inductor and electromagnet, there may occur a controlled braking or acceleration of the melt motion in the direction of a release chamber (that is, active control over the mass flow rate at casting can be executed).

In general, the level of melt in the chambers of MD-T (Fig. 3), in the absence of external physical activities, will be the same. However, it is possible to structurally execute a release chamber with an elevated level of the bottom part relative to the level of the bottom part of the release chamber. In this case, the connected induction channels between the chambers must be raised at the appropriate level or fabricated slanted in the direction of ascent from the receiving chamber to the release chamber. In this case, the relative height of the level of melt in the inlet chamber becomes significantly smaller than that in the release chamber. In addition, when one enables the electromagnet under a mode of braking the flow from the release chamber the level of the melt in the release chamber will be smallerIt is known [20] that the linear velocity of melt outflow from the container depends on the current level of liquid $H(\mathrm{~m})$ in this container:

$$
v=\mu(2 \cdot g \cdot H)^{1 / 2}, \mathrm{~m} / \mathrm{s}
$$

where $\mu$ - coefficient of hydraulic resistance when leakage from the container, usually $\mu=(0.60 \ldots 0.95) ; g-$ free fall acceleration, $g=9.8 \mathrm{~m} / \mathrm{s}^{2}$.

Therefore, when reducing the level of melt in the release chamber of MD-T by 2-2.5 times compared with conventional tundishes (from $1.0 \mathrm{~m}$ to $0.4-0.5 \mathrm{~m}$ ), in accordance with (3), the vertical component 
of linear velocity of the melt in a crystallizer decreases by 1.4-1.6 times. That is, there are significantly improved conditions for the preparation of a billet in the crystallizer of CCM. First, the superheated steel does not deeply penetrate the body of a billet, thereby washing out the hardened part. Second, the trapped gas and non-metallic inclusions remain mainly in the area of a crystallizer and do not enter the area of secondary cooling and hardening of the final product.

The tundish is mounted on four power-measuring sensors (two on each side of the ladle), fixed on a stationary base. The outputs of the sensors are connected to the adder in the unit of mass measurements. The circuit also includes a unit for setting an instantaneous value for mass of the melt in a tundish. The outputs of both units are connected to the zero-block in the control unit over a stopper (gate) of the casting ladle connected to the drive. In addition, the outputs of a pair of sensors, located from the side of the release chamber, are connected, together with the output from the unit of pressure control, through a correction unit of power voltage to control units of the inductor and electromagnet. The cup of the release chamber is part of the crystallizer of CCM. Melt comes from a casting ladle through the stopper with the actuator to the inlet chamber of the tundish, and, from it, through the cup, into the crystallizer.

Control over the temperature of melt in the inlet and release chambers of the tundish is executed by using temperature sensors, connected, accordingly, to the thermocontroller with a digital temperature indicator.

Control over the level of melt in the inlet and release chambers of the tundish and crystallizer is executed by using the sensors of level connected to the control unit of the melt level.

The inductors and electromagnet are connected to a power unit, connected, through a control board, to a remote control. The microprocessor units for measuring the mass, pressure, and flow rate of melt are connected to the corresponding digital indicators, which makes it possible to monitor, if necessary, different parameters.

The MD-T ACS under construction implies two modes of operation: with and without stabilizing the mass flow rate. In any case, the process of continuous casting of melt proceeds as follows. At the initial state, a tundish is empty (that is, the indicator of melt mass is set to zero) and is in standby mode. In this case, no electric power is supplied to the inductor and the electromagnet. The operator's command from a control board triggers the stopper (gate) of a casting ladle with the melt starting to arrive to the inlet chamber of MD-T. The inductor is enabled after filling the induction channel. When an instantaneous value for the melt mass in a tundish reaches the estimated value, the zero-body is triggered in a unit for measuring the melt mass, and its flow rate in the inlet chamber stabilizes. In this case, the level of the melt in the release chamber also stabilizes to provide for the required constant of mass flow rate at casting and the constant level of the melt in the crystallizer of CCM. To ensure the predefined flow rate settings, the electromagnet may be enabled.

Experimental verification of the proposed technique to control mass flow rate was conducted at the experimental and technological facility in the department of magnetic hydrodynamics at the Physical-Technological Institute of Metals and Alloys NAS of Ukraine's (PTIMA NAS of Ukraine). The used prototype (a physical model) of MD-T was the magneto-weighting installation MDN-6A for aluminum alloys with a capacity of up to $630 \mathrm{~kg}$ of melt. The installation was additionally equipped with a strain gauge force sensor to control the instantaneous value for melt $m_{\text {vis }}$ directly at a discharge metal pipe. This magnitude depends on the level of melt in the installation and the magnitude of the generated electromagnetic force, which, at steady power to the inductor, is defined primarily by voltage at the electromagnet. It should be noted that the process of casting, because of the actions of several hydrodynamic factors, is accompanied by pulsations of the melt jet. At continuous casting with an open jet from a tundish to the crystallizer of CCM, this leads to splattering and secondary oxidation of the metal. For the case of casting using a cup submerged under the melt level in crystallizer, its cavity is washed, which also degrades quality of a billet. Therefore, in the course of the experiment, in order to reduce the influence of jet pulsations on the process of casting, we applied a dimensionless criterion $k$ :

$$
k=Q / m_{\text {vis }},
$$

where $Q$ is the mass flow rate of melt when casting, $\mathrm{kg} / \mathrm{s}$.

In the course of the experiment that involved the casting of an aluminum alloy it was established that the minimal jet pulsations are achieved at values of $k$ from 2.2 to 2.25. Maintaining this indicator at discrete casting of the melt in portions weighing $1.8 \mathrm{~kg}$ ensured the high precision of dispensing (Fig. 4). The error amounted to $1.5 \%$ by weight of a dose. For comparison, at dosed casting of portions up to $3 \mathrm{~kg}$, for example in the injection molding technology, without the use of magnetodynamic equipment and the proposed magneto-weighting system, an error can be up to $5 \%$ [21].

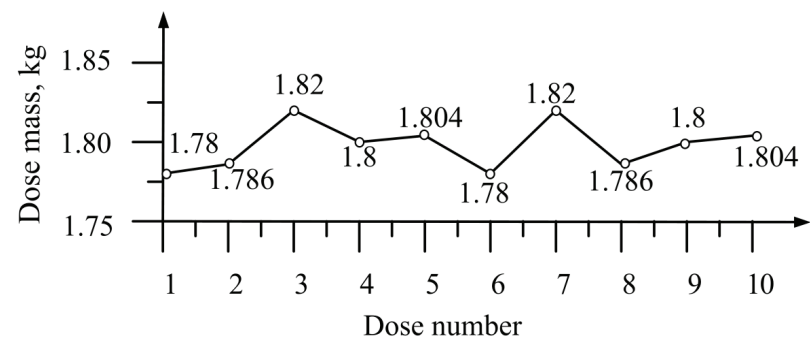

Fig. 4. Discrete dispensing of aluminum melt in portions weighing $1.8 \mathrm{~kg}$ using a magnetodynamic installation that is equipped with a weight-measuring strain-gauge sensor

Thus, the implementation of the magneto-weighting technique to control continuous melt casting ensures stability of the process, confirmed by the above results from experimental research at existing and model magnetodynamic equipment. In particular, active control over the thermal state of melt in MD-T reduces the probability of defect occurrence, associated with adverse temperature mode of casting. Control over flow rate characteristics would make it possible to increase the output of suitable casting and the process efficiency.

\section{Discussion of results of research into constructing a new system for automated control over a magnetodynamic tundish}

Comparing the designed MD-T ACS to conventional technologies of managing continuous casting (Fig. 5, 
Table 1) demonstrates the following. Existing types of technological equipment are not always adaptable to each other, not synchronized with each other, not interchangeable, and it is difficult to integrate them into a single system. The proposed technique and assemblies make it possible to reduce the number of interconnected units and create proper conditions for the development of the process and the improvement of its technical and economic indicators.
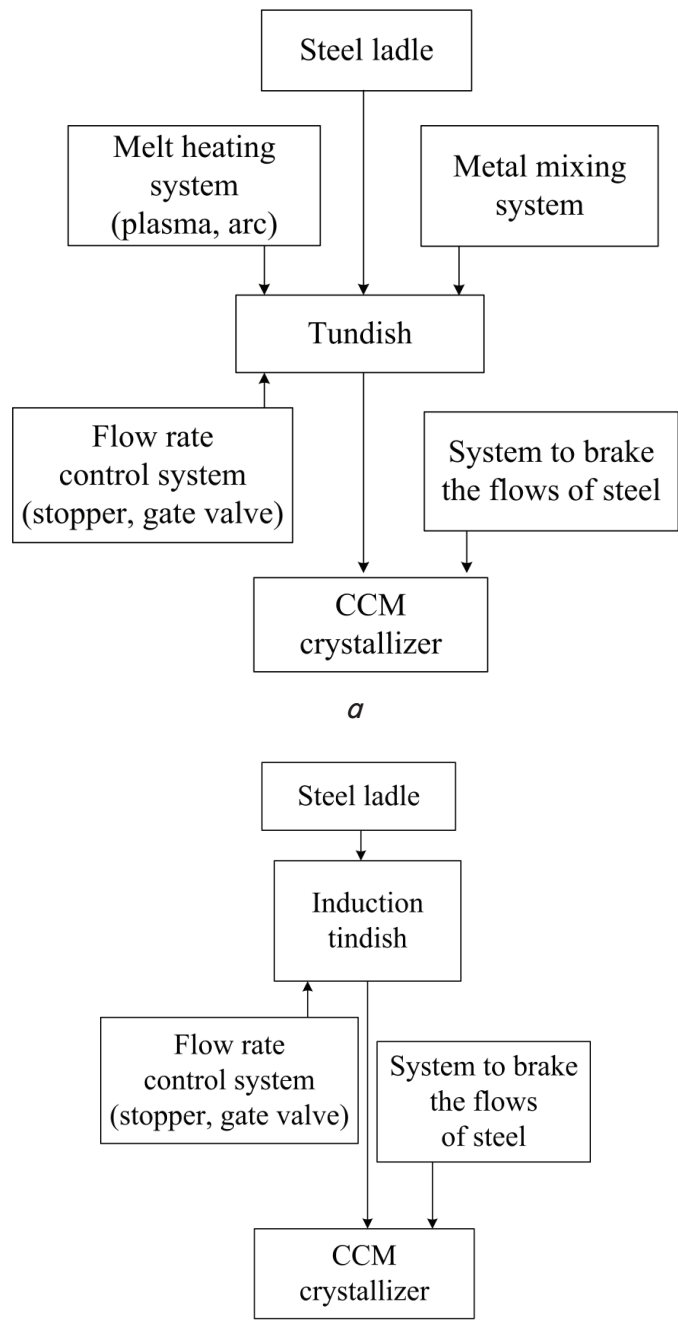

$b$

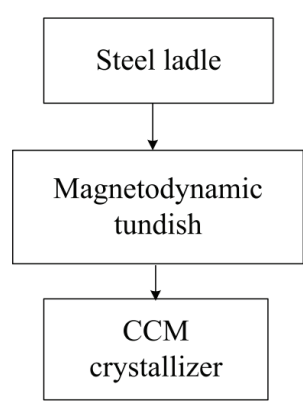

c

Fig. 5. Comparison of schemes of continuous steel casting process: $a-$ technology that employs a conventional tundish; $b$ - technology that employs an induction tundish; $c$ - technology that employs a magnetodynamic tundish
Table 1

Comparison of characteristics of tundishes with various designs

\begin{tabular}{|l|c|c|c|}
\hline \multicolumn{1}{|c|}{ Characteristic } & $\begin{array}{c}\text { Conven- } \\
\text { tional } \\
\text { tundish }\end{array}$ & $\begin{array}{c}\text { Induc- } \\
\text { tion } \\
\text { tundish }\end{array}$ & $\begin{array}{c}\text { Magneto- } \\
\text { dynamic } \\
\text { tundish }\end{array}$ \\
\hline Relative simplicity of design & $++*$ & + & + \\
\hline Worked-out operations & ++ & + & + \\
\hline Novelty of technical solutions & - & + & ++ \\
\hline $\begin{array}{l}\text { Effective heating of metal without } \\
\text { the use of additional systems }\end{array}$ & - & + & + \\
\hline $\begin{array}{l}\text { Stirring a melt without the use of } \\
\text { additional systems }\end{array}$ & - & + & ++ \\
\hline $\begin{array}{l}\text { Possibility to intensify the proces- } \\
\text { ses of out-of-furnace metal pro- } \\
\text { cessing }\end{array}$ & - & + & + \\
\hline $\begin{array}{l}\text { Possibility of casting a melt with- } \\
\text { out the use of mechanical devices }\end{array}$ & - & - & + \\
\hline $\begin{array}{l}\text { Stability of a steel jet outflow from } \\
\text { a tundish to the crystallizer }\end{array}$ & + & + & ++ \\
\hline $\begin{array}{l}\text { Possibility of low-head casting and } \\
\text { decrease in the dynamic impact of } \\
\text { a steel jet }\end{array}$ & - & - & + \\
\hline $\begin{array}{l}\text { Possibility to effectively control } \\
\text { the process of continuous casting } \\
\text { and decrease in the probability of } \\
\text { breakthroughs }\end{array}$ & - & + & ++ \\
\hline $\begin{array}{l}\text { Possibility to improve the condi- } \\
\text { tions for the distribution of metal } \\
\text { across the width of the crystallizer }\end{array}$ & - & - & ++ \\
\hline $\begin{array}{l}\text { No need to use inert gases to pro- } \\
\text { tect the elements of stopper or slide } \\
\text { systems }\end{array}$ & - & - & + \\
\hline Product quality improvement & - & + & ++ \\
\hline Material- and energy saving & - & + & ++ \\
\hline
\end{tabular}

Note: * Estimates: «-«- fair; «+»- good; «++»-very good.

Based on the analysis of available information and the above research results, one can formulate general recommendations to the sample of MD-T under construction:

- capacity - 3-10 tons of liquid steel;

- total electrical power of inductors - 300-600 kW;

- control system - an integrated weight-measuring one, using strain-gauge sensors, as well as providing a possibility for additional application of modern sensors of melt level;

- scope of application - continuous casting of thin slab, obtaining sheet metal articles directly from the melt by casting - rolling in a two-roller crystallizer, obtaining highquality steel billets under conditions of metallurgical miniand micro enterprises.

The current research should be advanced in two basic areas.

First, it is required to thoroughly work out the time, temperature, and flow rate ratios across all links within a technological process - from a smelting unit to the crystallizer of $\mathrm{CCM}$ - in actual industrial settings.

Second, it is necessary to adapt the devised approaches, equipment, and systems, to the most promising technologies in continuous casting of alloys. Today these include obtaining a thin slab, direct production of a steel sheet from melt using the technology of casting to a two-roller crystallizer, as well as manufacturing high-quality billets under conditions of small steel enterprises. 


\section{Conclusions}

1. It has been proposed to improve the processes of continuous casting of metals and alloys based on applying a magnetodynamic tundish designed in Ukraine. We have devised a new principle to control the flow rate characteristics, as well as a corresponding ACS, based on using an integrated weight-measuring system.

2. Based on the results from full-scale and model experiments, the proposed development would ensure the controlled induction superheating of melt immediately before its release to the crystallizer of CCM. Also implemented is contactless control over the motion of a liquid metal (its stirring and release to the crystallizer of CCM) under the action of electromagnetic forces. In addition, it becomes possible to cast alloys under low head with a controlled mass flow rate and to supply melt across the entire width of the crystallizer of CCM.

3. The expected economic benefits of using MD-T and the proposed ACS imply a decrease in the number of technological operations with melt and the related energy saving in stabilizing the operation of CCM, improvement of quality of continuously-cast workpieces, larger output of suitable casting and enhanced process efficiency.

\section{References}

1. Al'tgauzen, A. P. et. al.; Al'tgauzen, A. P. (Ed.) (1980). Elektrotermicheskoe oborudovanie. Moscow: Energiya, 303.

2. Mabuchi, M., Yoshii, Yu., Nozaki, Ts. et. al. (1985). Automatic Control of Molten Steel Temperature in Tundish and Application to Stainless Steel Casting. Kawasaki Steel Giho, 14 (4), 365-371.

3. Takeuchi, E., Zeze, M., Toh, T., Mizoguchi, Sh. (1992). Applied MHD in the Process of Continuous Casting. Proceedings of Symposium «Magnetohydrodynamics in Process Metallurgy» (during the TMS Annual Meeting). San Diego, California, 189-202.

4. Wang, Q., Li, B., Tsukihashi, F. (2014). Modeling of a Thermo-Electromagneto-Hydrodynamic Problem in Continuous Casting Tundish with Channel Type Induction Heating. ISIJ International, 54 (2), 311-320. doi: https://doi.org/10.2355/isijinternational.54.311

5. Tang, H., Guo, L., Wu, G., Xiao, H., Yao, H., Zhang, J. (2018). Hydrodynamic Modeling and Mathematical Simulation on Flow Field and Inclusion Removal in a Seven-Strand Continuous Casting Tundish with Channel Type Induction Heating. Metals, 8 (6), 374. doi: https://doi.org/10.3390/met8060374

6. Taniguchi, S., Brimacombe, J. K. (1994). Separation of nonmetallic inclusions from liquid metal by pinch force. Proceedings of the International Symposium on Electromagnetic Processing of Materials «EPM 1994». Nagoya, 429-434.

7. Taniguchi, S., Brimakomb, Dzh. (1996). Izvlechenie nemetallicheskih vklyucheniy iz metalla siloy pincha. Magnitnaya gidrodinamika, 2, 158-163.

8. Miki, Yu. (2006). Applications of MHD to continuous casting of steel. Proceedings of the 5th International Symposium on Electromagnetic Processing of Materials «EPM 2006». Sendai, 26-30.

9. Toh, T., Takeuchi, E., Matsumiya, T. (2006). Recent advances in MHD applications to steelmaking processes. Proceedings of the 5th International Symposium on Electromagnetic Processing of Materials «EPM 2006». Sendai, 21-25.

10. Dubodelov, V. I., Smirnov, A. N., Efimova, V. G., Kravchenko, A. V., Verzilov, A. P. (2018). Gidrodinamicheskie i fiziko-himicheskie protsessy v promezhutochnyh kovshah dlya nepreryvnogo lit'ya stali. Kyiv: Naukova dumka, 264.

11. Cho, S.-M., Kim, S.-H., Thomas, B. G. (2014). Transient Fluid Flow during Steady Continuous Casting of Steel Slabs: Part I. Measurements and Modeling of Two-phase Flow. ISIJ International, 54 (4), 845-854. doi: https://doi.org/10.2355/ isijinternational.54.845

12. Cho, S.-M., Kim, S.-H., Thomas, B. G. (2014). Transient Fluid Flow during Steady Continuous Casting of Steel Slabs: Part II. Effect of Double-Ruler Electro-Magnetic Braking. ISIJ International, 54 (4), 855-864. doi: https://doi.org/10.2355/ isijinternational.54.855

13. Wang, E. (2015). Progress of some techniques on electromagnetic metallurgy. Proceedings of the 8th International Conference on Electromagnetic Processing of Materials «EPM 2015». Cannes.

14. Louhenkilpi, S., Law, W., Serna, M., Välimaa, K., Leuverink, D., Rodríguez Durán, T. et. al. (2013). Active tundish metallurgy. Luxembourg: Publications Office of the European Union. doi: http://doi.org/10.2777/62336

15. Yue, Q., Zhang, C. B., Pei, X. H. (2017). Magnetohydrodynamic flows and heat transfer in a twin-channel induction heating tundish. Ironmaking \& Steelmaking, 44 (3), 227-236. doi: https://doi.org/10.1080/03019233.2016.1209919

16. Dubodelov, V., Smirnov, A., Pogorsky, V., Goryuk, M. (2006). The magnetodynamic tundish for continuous casting of steel. Proceedings of the 5th International Symposium on Electromagnetic Processing of Materials «EPM 2006». Sendai, 114-119.

17. Wang, G., Yun, M., Zhang, C., Xiao, G. (2015). Flow Mechanism of Molten Steel in a Single-Strand Slab Caster Tundish Based on the Residence Time Distribution Curve and Data. ISIJ International, 55 (5), 984-992. doi: https://doi.org/10.2355/ isijinternational.55.984

18. Horiuk, M. S., Dubodelov, V. I., Bohdan, K. S., Fikssen, V. M., Pohorskyi V. K. (2003). Pat. No. 66035 UA. Pony ladle of continuous casting machine. No. 2003076633; declareted: 15.07.2003; published: 15.04.2004, Bul. No. 4.

19. Pohorskyi, V. K., Bohdan, K. S., Dubodelov, V. I., Horiuk, M. S., Fikssen, V. M. (2004). Pat. No. 67965 UA. Method for control of metal melt consumption. published: 15.07.2004, Bul. No. 7.

20. Idel'chik, I. E. (1975). Spravochnik po gidravlicheskim soprotivleniyam. Moscow: «Mashinostroenie», 560.

21. Efimov, V. A., Anisovich, G. A., Babich, V. N. et. al. (1991). Spetsial'nye sposoby lit'ya. Moscow: Mashinostroenie, 436. 